\title{
Overcoming the Shock of Foreign Cultures through Cross- Cultural Understanding
}

\author{
Mustakim ${ }^{1}$, Umiyati Jabri² \\ ${ }^{1-2}$ English education Department, Universitas Muhammadiyah Enrekang, Indonesia \\ Email: ${ }^{1}$ kimchangi00@gmail.com; ${ }^{2}$ umiyatijabri@gmail.com
}

\section{ARTICLE INFO}

Article History:

Received June 10, 2020

Revised June 16, 2020

Accepted July 16, 2020

Keywords:

Culture Shock, Cross-

Cultural Understanding,

Foreign Culture

\begin{abstract}
This paper seeks to slightly explore the issue of cross-cultural understanding that might be beneficial for lecturers of the Muhammadiyah University of Enrekang who have won further study scholarships abroad as well as lecturers who are planning to continue their studies abroad. Understanding different cultures are extremely fundamental as a result of the absence of information culture assumes a job in the utilization of improper correspondence language. Elements of contrasts in an individual's way of life can likewise make individuals look prejudiced toward individuals with various societies. As a lecturer who will be assigned to study abroad, it is very important to "interpret" the behavior, attitudes, and communication styles of people from various cultures. Sometimes hinder a person to be able to complete studies abroad is not because of limited intelligence but because of limited ability to understand and accept the new culture contained in the destination country to learn. We hope that this paper can provide a little inspiration for prospective scholarship recipients of foreign scholarships to prepare themselves as well as possible including non-academic factors.
\end{abstract}

Introduction

Besides having a very important role in the development of the nation through the creation and the development of science and technology, universities have obligations to provide competently and characterized human resources. Therefore, Higher education must always strive to develop and progress. The main focus of the progress of a tertiary institution lies in the availability 
of qualified lecturers because the quality of lecturers will largely determine the quality of the tertiary institution.

We can see the central role of lecturers in improving the quality of education various legal and regulatory products in Indonesia, including Law Number 202003 concerning the National Education System, Law Number 14 of 2005 concerning Teachers and Lecturers, Government Regulation Number 37 of 2009 concerning Lecturers, and Minister of National Education Regulation Number 42 the Year 2007 regarding Lecturer Certification. One of the important things that can be drawn from the legislation is qualifications and lecturer competencies that are strictly regulated. For example, in legislation, it is expressly stated that lecturers must have academic education strata at least one level higher than the educational strata they teach.

Efforts to improve the competence and quality of lecturers have been made by the government Indonesia through the Directorate General of Higher Education, Ministry of Education and Culture by providing scholarships for further study both domestically and abroad. In an effort to shortening the quality of higher education with other countries, the Directorate General of Higher Education has a program to send lecturers from Indonesian tertiary institutions to study continued abroad through various schemes. Some international aid agencies also provide opportunities for Indonesian lecturers to continue their education outside the country as the number of lecturers studying abroad each year is increasing.

Although the overseas scholarship program has been designed quite well, there are several aspects that must be considered to support the success of a lecturer abroad. One of the aspects is quite important to be honed is the ability of lecturers who study abroad to understand the culture and habits of the country where the person studies. This is important because the understanding culture is very supportive and can even determine the success of the study.

Based on some of the things that have been stated above, this paper seeks to slightly explore the issue of crosscultural understanding that might be beneficial for lecturers of the Muhammadiyah University of Enrekang who have won further study scholarships abroad as well as lecturers who are planning to continue their studies abroad.

\section{Discussion}

\section{The Importance of Cross-Cultural Understanding}

In this globalization era, the world seems to be "shrinking" so that our intensity to connect with foreign people and cultures will be higher. Moreover, when it is connected with our desire to realize a world-class university, our interactions with foreign people and cultures will become increasingly frequent both through academic collaboration, joint research and the most intense is when we carry out study assignments abroad. Therefore a wider capacity to understand cultural diversity is needed (Jabri, U., \& Samad, I., 2019). Although it has been proven that all cultures and functions and are important for members of these cultures, sometimes when viewed in the eyes of other cultural members have different values. Despite the fact that they have various qualities compared to different 
societies, every person and/or culture has the privilege to utilize its own qualities. In this manner, understanding different societies is extremely important due to the absence of information culture assumes a job in the utilization of wrong correspondence language. Elements of contrasts in an individual's way of life can likewise make individuals look bigoted of individuals with various societies. As a lecturer who will be assigned to study abroad, it is very important to "interpret" the behavior, attitudes, and communication styles of people from various cultures. We should likewise comprehend that singular contrasts are significant, yet there are principal social presumptions and examples that apply all around. However, before attempting to understand other people's cultures, understanding one's own cultural values is a prerequisite for identifying and understanding other cultural values. Cross-cultural and interpersonal understanding of others is an effort that requires courage as well as sensitivity. By overcoming cultural barriers we will gain understanding and appreciation for human needs, aspirations, feelings (Ismail, I., 2019) and problems.

\section{Inter-Cultural Communication}

Intercultural communication is a process where people who have cultural differences can send and receive messages to interpret signals in different ways both verbally and nonverbally. The acquired communication skills will allow a person to be moved from a singlecultural perspective to more multicultural points of view, and will therefore likely help study abroad smoothly. There are several cultural communication contexts in this world.
We must know each type so that we can avoid conflict just because miss understanding the meaning of the communication from people who have different communication cultures.

There are two types of culture in communication, namely high culture context and low culture context. The following are the two forms of contact contexts: (a.) high context Culture: this culture is based primarily on non-verbal and subtle communicative points (Nishimura et al., 2009). What is conveyed is not always the revealed meaning. Those items are very much used in Javanese society. Face, body language, and others are transmitted. (b) Culture with low context: this culture relies heavily on words to communicate meaning. What is transmitted is the meaning of the word. Therefore, people with such a culture typically pay close attention to what the speaker is saying.

The figure 1 is a representation of the types of communication contexts from various countries. The more downward, the lower the context of communication. In the picture, it appears that countries in Asia (actually including Java, Malay, Thailand, etc.) have a high cultural context. Latinos, Spaniards, Italians occupy the center of the picture. They usually speak expressively and use hand or head movements or eye movements to express emotions. Germans or Swiss put more emphasis on verbal expressions that actually mean to express their intentions. Therefore we know these people as zakelijk or to-thepoint people.

Figure 1: A typology of the nature of human communication based on country of origin 


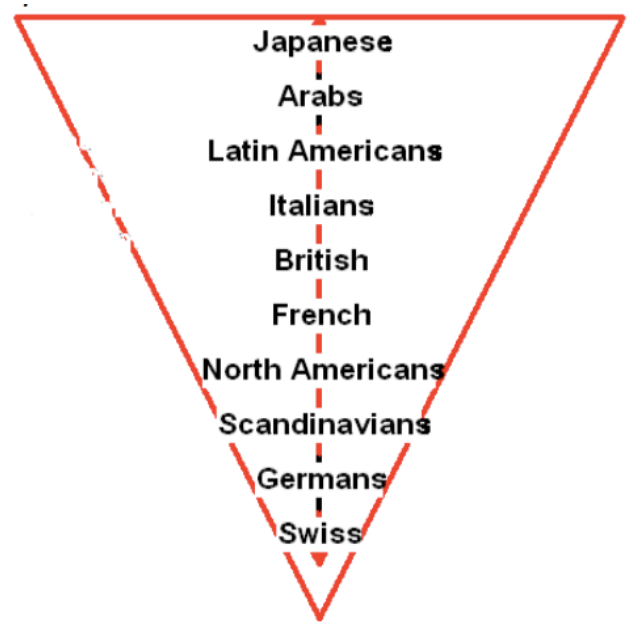

\section{Variations in communication between cultures}

In communicating, there are several things that we must pay attention to so that the true intentions of what we want to convey can be expressed properly. In addition to paying attention to verbal communication, we must also pay attention to our non-verbal communication. Several things to note are:

Verbal communication: In verbal communication, the choice of words used can affect whether or not our communication is good. Although in an area the words used are considered normal, it is conceivable that different words are considered rude, so there is a possibility that it will cause offense. Volume and tone of voice too influential on the success of our communication. A loud volume can indicate firmness, a weak means less firm. High pitch tone is generally considered to be angry and so forth.

Non-verbal:

non-verbal communication is important as well. When we communicate with others we must pay attention: personal space (some cultures don't like it when talking too close, while others prefer it close together), touch (touch in some parts of the body is an insult to some cultures, touch between men and women also must be considered), facial expressions (can show our emotions), eye contact (Western people want us to look them in the eye when talking because it shows our seriousness), posture (including how to sit, hand position when talking, etc.).
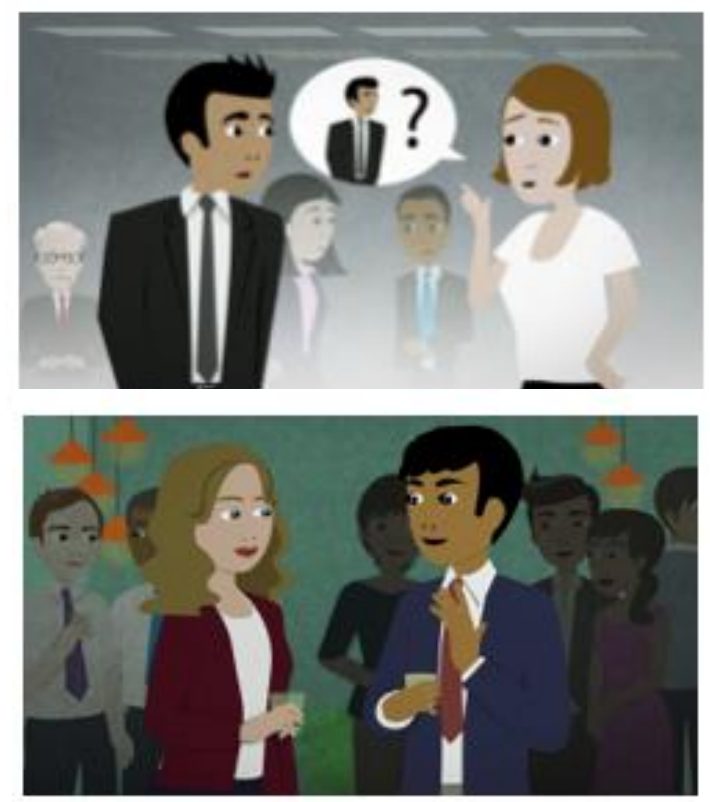

Figure 2.2: Confusion at the first meeting (Source: PhraseMix.com)

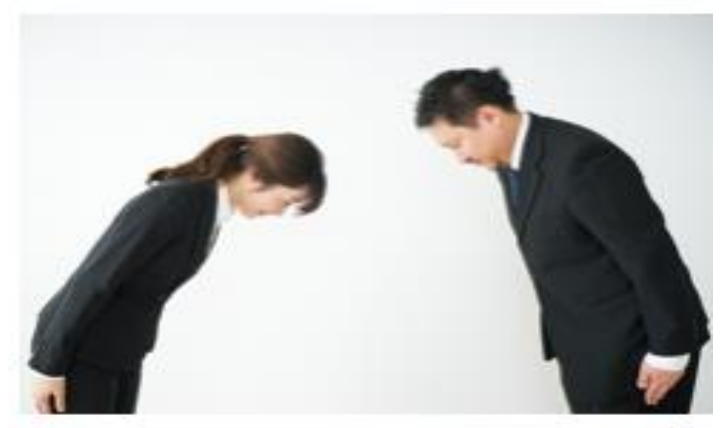

Figure 2.3: Various ways to give greetings (from various sources) 


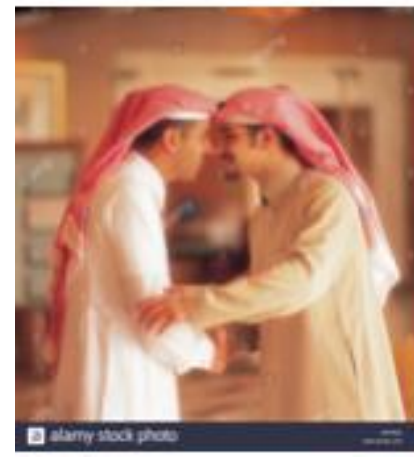

\section{Culture Shock}

Culture shock is one thing that also needs to be considered when someone, including lecturers, is going to study further abroad. Culture shock is often a stone stumbling to a lecturer when carrying out study assignments abroad. Culture shock is often considered a natural thing for most people, but it should not be underestimated because it can lead to acute depression for some people.

Culture shock is closely related to circumstances where there are excessive worry and confusion experienced by people who occupy new and unfamiliar territory. Usually, people who experience culture shock are those who are relatively unstable in adapting. Different environmental conditions that are usually found in the country, such as the home environment, different types of food, campus atmosphere, and lectures, associations with people who are not as expected are known to be one of the factors causing culture shock symptoms.

Usually, observers divide the four stages of the emergence of culture shock, namely:

\section{The Honeymoon Phase}

In this phase, people who are studying further abroad will usually feel happy upon arrival in a new country, especially a country that has never been visited before. Usually, everything that is new feels interesting and exciting.

\section{The Crisis Phase}

In this phase, the differences in a new country are starting to feel inappropriate or boring. Things that are not right this can be in the form of food (difficulty finding food that suits the tongue, difficulty finding halal food, etc.), difficult language understandable (especially in countries that do not speak English), association with new environments and new habits and begin to be lonely because of distant relatives. In this phase, collisions often occur as analogous to the two icebergs colliding.

\section{The Adjustment Phase}

This phase is very important because whether or not we succeed through a culture shock depends on our ability to make adjustments. In this phase, it is hoped that lecturers who are studying further have begun to be able to interact with the environment in the new country and find ways to make adjustments.

\section{Bi-Cultural Phase}

After successfully passing the previous phases, lecturers who study abroad will experience this phase. He can already feel comfortable living with two cultures at the same time (biased to adjust). Nevertheless, there must be a balance between understanding foreign culture without leaving our identity as Indonesian people.

Because this culture shock is a "nontechnical" issue that can hamper the 
success of a lecturer conducting further studies abroad, it is important to know some things that can be used as anticipation or minimize the impact of culture shock. From some experiences, there are several ways to overcome this culture shock:

1. Enlarge insight into the country of study destination. The best way is to read a guidebook about the destination country, ask people who have lived there, or browse information on the internet. Never imagine that life abroad as we see it in movies and on television. This is to avoid disappointment or misunderstanding because what we imagine does not correspond to reality.

2. Looking for information about culture, life habits, sports that are popular in the destination country to the topic of daily conversation and body language that is commonly used in the country.

3. Upon arrival in the destination country, immediately try to recognize local life and know important places such as post offices, food shops, doctors, and international student service offices. If something does not go according to plan, you have to be brave to ask questions about circumstances and customs in the new place. Getting used to reading local newspapers so we know the topic of conversation that latest and can be discussed. This can help speed up social adjustments to the new environment.

\section{Conclusion}

From many things that must be prepared before the departure of a lecturer to study abroad, cultural understanding and preparation for facing cultural differences are considered very important. Sometimes hinder a person to be able to complete studies abroad is not because of limited intelligence but because of limited ability to understand and accept the new culture contained in the destination country to learn. We hope that this paper can provide a little inspiration for prospective scholarship recipients of foreign scholarships to prepare themselves as well as possible including non-academic factors.

\section{References}

1) Jabri, U., \& Samad, I. (2019). The Use of Indonesian Slang by Makassar Families in Their Daily Interaction. MAJESTY JOURNAL, 1(2), 10-18. https://doi.org/10.33487/majesty.v $\underline{1 i 2.116}$

2) Ismail, I. (2019). The Impact of Interactive Reading Using Local Folktales Stories in Supporting Students' Vocabulary Achievement in Indonesian EFL Learners. MAJESTY JOURNAL, 1(2), 25-37. https://doi.org/10.33487/majesty.v $\underline{1 \mathrm{i} 2.119}$

3) Ismail, I. (2019). Converting a Story from Students' Own Language in English to Increase Speaking Ability. MAJESTY JOURNAL, 1(1), 5-18. https://doi.org/10.33487/majesty.v $1 \mathrm{i} 1.54$

4) Levine, D. R., \& Adelman, M. B. (1982). Beyond language: Intercultural communication for English as a second language. Englewood Cliffs, N.J: Prentice-Hall

5) Mustakim, Salman. (2019). Character Building Based on Local Culture (Case Study on State Senior High School 4 Enrekang). Edumaspul: Jurnal Pendidikan - Vol 3 No. 2 (2019) page 22 - 30. DOI: 
https://doi.org/10.33487/edumasp ul.v3i2.133

6) Mustakim, M., Doloh, S., \& Busa, Y. (2020). International Community Service Program Model for Teacher Prospective Students at STKIP Muhammadiyah Enrekang. MAJESTY JOURNAL, 2(1), 31-39. https://doi.org/10.33487/majesty.v $\underline{2 i 1.330}$

7) Nishimura, S., Anne Nevgi, and Seppo Tella, (2009). Communication Style and Cultural Features in High/Low Context Communication Cultures: A Case Study of Finland, Japan, and India. Retrieved from www.helsinki.fi/ tella/nishimuran evgitella299.pdf.
Majesty Journal, 2 (2), 2020 - 31 Mustakim; Umiyati Jabri

8) Pedoman Beasiswa Pendidikan Pascasarjana Luar Negeri, Direktorat Jenderal Pendidikan Tinggi Tahun Anggaran 2013. Retrieved from (http://studi.dikti.go.id/studi/uploa d/2013/PEDOMAN BLN DIKTI2013.pdf).

9) Peraturan Menteri Pendidikan Nasional No. 42 th. 2007 Tentang Sertifikasi Dosen

10) Undang-Undang Nomor 20 Tahun 2003 tentang Sistem Pendidikan Nasional

11) Undang-Undang Republik Indonesia Nomor 14 Tahun 2005 Tentang Guru dan Dosen 